MT-DP - 2017/36

\title{
Portfolio valuation under liquidity constraints with permanent price impact
}

\author{
PÉTER CSÓKA - JUDIT HEVÉR
}


Discussion papers

MT-DP - 2017/36

Institute of Economics, Centre for Economic and Regional Studies, Hungarian Academy of Sciences

KTI/IE Discussion Papers are circulated to promote discussion and provoque comments. Any references to discussion papers should clearly state that the paper is preliminary. Materials published in this series may subject to further publication.

Portfolio valuation under liquidity constraints with permanent price impact

Authors:

Péter Csóka

senior research fellow

"Momentum" Game Theory Research Group

Centre for Economic and Regional Studies, Hungarian Academy of Sciences and Department of Finance, Corvinus Business School, Corvinus University of Budapest E-mail: peter.csoka@uni-corvinus.hu

Judit Hevér

Department of Finance, Corvinus Business School, Corvinus University of Budapest and Pallas Athéné Domus Educationis Scholarship

E-mail:judit.hever@stud.uni-corvinus.hu

December 2017

ISBN $978-615-5754-34-0$

ISSN $1785377 \mathrm{X}$ 


\title{
Portfolio valuation under liquidity constraints with permanent price impact
}

\author{
Péter Csóka - Judit Hevér
}

\begin{abstract}
When institutional investors rearrange their portfolios, they should consider both the temporary and the permanent price impacts. After a temporary price impact the order book fully recovers, whereas a permanent price impact changes the equilibrium price, having effects on the resulting portfolio.

In this paper, for a given period, we introduce an optimization problem for valuing illiquid portfolios with permanent price impacts. We show how to find the optimal trade to satisfy certain portfolio constraints. As a policy implication, we note that introducing permanent price impacts in internal or external regulation can substantially change liquidity risk or capital requirements.
\end{abstract}

Keywords: Portfolio Valuation, Liquidity Risk, Permanent Price Impact, SEC Rule 22e-4

JEL classification: G11

\section{Acknowledgement:}

We would like to thank Carlo Acerbi, Tamás László Bátyi, Miklós Pintér, Tamás Vadász, and participants of the 6th Annual Financial Market Liquidity Conference for helpful comments. Péter Csóka was supported by the ÚNKP-17-4-III New National Excellence Program of the Ministry of Human Capacities. 


\title{
Portfólióértékelés likviditási korlátok \\ és permanens árhatás mellett
}

\author{
Csóka Péter - Hevér Judit
}

\section{Összefoglaló}

Amikor intézményi befektetők átrendezik a portfóliójukat, akkor az ideiglenes és a permanens árhatásokat is érdemes figyelembe venniük. Ideiglenes árhatás után az ajánlati könyv teljesen visszaépül, viszont a permanens árhatás megváltoztatja az egyensúlyi árakat, aminek hatása van a keletkezett portfólióra.

Tanulmányunkban mutatunk egy optimalizációs feladatot adott időszakra vonatkozóan illikvid portfóliók értékelésére a permanens árhatást is figyelembe véve. Megmutatjuk, hogyan lehet optimálisan kereskedni bizonyos portfóliókorlátok mellett. Gazdaságpolitikai következményként felhívjuk a figyelmet arra, hogy a permanens árhatások bevezetése belső vagy külső szabályozói nyomásra jelentősen megváltoztathatja a likviditási kockázatot vagy a tőkekövetelményeket.

Tárgyszavak: portfólióértékelés, likviditási kockázat, permanens árhatás, SEC 22e-4 szabályozás

JEL: G11 


\title{
Portfolio valuation under liquidity constraints with permanent price impact*
}

\author{
Péter Csóka†and Judit Hevér ${ }^{\ddagger}$
}

December 2017

\begin{abstract}
When institutional investors rearrange their portfolios, they should consider both the temporary and the permanent price impacts. After a temporary price impact the order book fully recovers, whereas a permanent price impact changes the equilibrium price, having effects on the resulting portfolio.

In this paper, for a given period, we introduce an optimization problem for valuing illiquid portfolios with permanent price impacts. We show how to find the optimal trade to satisfy certain portfolio constraints. As a policy implication, we note that introducing permanent price impacts in internal or external regulation can substantially change liquidity risk or capital requirements.
\end{abstract}

Keywords: Portfolio Valuation, Liquidity Risk, Permanent Price Impact, SEC Rule 22e-4

JEL Classification: G11

*We would like to thank Carlo Acerbi, Tamás László Bátyi, Miklós Pintér, Tamás Vadász, and participants of the 6th Annual Financial Market Liquidity Conference for helpful comments.

${ }^{\dagger}$ Department of Finance, Corvinus Business School, Corvinus University of Budapest and "Momentum" Game Theory Research Group, Centre for Economic and Regional Studies, Hungarian Academy of Sciences. E-mail: peter.csoka@uni-corvinus.hu. Péter Csóka was supported by the ÚNKP-17-4-III New National Excellence Program of the Ministry of Human Capacities.

${ }_{\ddagger}^{\ddagger}$ Department of Finance, Corvinus Business School, Corvinus University of Budapest and Pallas Athéné Domus Educationis Scholarship. E-mail:judit.hever@stud.unicorvinus.hu 


\section{Introduction}

When institutional investors convert part of their illiquid portfolio to cash, or rearrange their portfolio in general, they should consider both the transaction costs and the effects on the resulting portfolio. Almgren and Chriss (2000) and Almgren (2003) define temporary and permanent price impact functions to determine optimal execution strategies. During trading, supply-demand imbalances cause temporary price impact and hence transaction costs. In this case, there are temporary price fluctuations from the equilibrium price, but by the end of the period, the order book fully recovers. On the other hand, the permanent price impact changes the equilibrium price of the resulting portfolio for the whole liquidation time horizon, and there is no full price recovery. To value illiquid portfolios for a given period, Acerbi and Scandolo (2008) assumes that there is no permanent price impact, which is a reasonable assumption for smaller trades and longer time horizons, or for assets having a relatively certain fundamental value like short-term bonds. There is also no permanent price impact in the recent Rule 22e-4! adopted by the SEC to regulate registered open-end funds' liquidity risk, since what Rule 22e-4 wants to avoid is the spillover of transaction costs between investors in the same fund, and not the changes in the equilibrium prices.

To determine the value of an illiquid portfolio, Acerbi and Scandolo (2008) uses Marginal Supply-Demand Curves (MSDCs) of the assets within the portfolio and a liquidity policy. Given a period, the MSDC of a risky asset expresses the marginal bid prices (for positive quantities) and marginal asks (for negative quantities) at which the particular asset can be traded. A liquidity policy specifies the portfolio constraints, for instance, the minimum level of cash to be reached for an open-end fund to be able to meet its obligations to redeeming shareholders. In general, the liquidity policy serves as the acceptable set of portfolios, and can model the requirement that having more risky assets requires strictly more cash. Acerbi and Scandolo (2008) shows that the value of an illiquid portfolio without permanent price impact is given as a convex optimization problem, where an attainable portfolio within the liquidity policy should be reached with the lowest transaction costs.

The permanent price impact, however, can be relevant for larger trades and shorter time horizons, and for assets having a relatively uncertain fundamental value. In this paper, to the best of our knowledge, given a period, we are the first to provide an optimization problem for valuing illiquid portfolios with permanent price impacts. We also assume that the temporary effects are

\footnotetext{
${ }^{1}$ Securities and Exchange Commission's Investment Company Liquidity Risk Management Programs, 17 CFR Parts 210, 270, 274, effective January 17, 2017, and partly from June 1, 2018. https://www.sec.gov/rules/final/2016/33-10233.pdf.
} 
dissipated by the time the portfolio constraints (the liquidity policy) should be satisfied, but we incorporate permanent price impacts. Huberman and Stanzl (2004) shows that a linear permanent price impact function is needed for arbitrage-free pricing. Moreover, Almgren et al. (2005) tests empirically and cannot reject the hypothesis of a linear permanent price impact. We also use a linear permanent price impact function, which means that depending on the size of the trade, selling decreases and buying increases the level of the corresponding MSDC linearly.

Intuitively, there is an endowment effect on top of the transaction cost effect that should be taken into account when valuing illiquid portfolios with permanent price impacts. The trade-off is between trading more from a rather liquid asset to have lower transaction costs, and trading less to cause lower permanent price impact on the remaining endowment from the particular asset. In general, solving the optimization problem requires numerical methods or further assumptions. As a special case, we consider a cash liquidity policy with no short positions (Csóka, 2017), where the acceptable portfolio should have a minimum level of cash and short positions should be closed. To get analytical results, one can approximate the MSDCs with exponential functions (Tian et al., 2013). As a policy implication, we note that introducing permanent price impacts in internal or external regulation can substantially change liquidity risk or capital requirements.

In a sense, what we capture is that an institutional investor or any investor with large enough stakes has the power to influence or even manipulate the value of certain assets, which is also documented in recent studies. In the Saudi Stock Market, Alzahrani et al. (2012) finds an asymmetry in the price impact of block purchases and sales. Han et al. (2016) and Kitamura (2016) analyze data from order-driven markets to examine the price impact of informed trading. Han et al. (2016) confirms the presence of informed trading by finding that a substantial portion of the price impact is persistent. Comparing the market impact of small and large trades, Han et al. (2016) finds that the price impact for institutional investors is larger than for individuals, and concludes that stealth trading is usual. Kitamura (2016) also shows a significant price impact of informed trading.

The structure of the paper is the following. In Section 2, we give the notation, wrap up portfolio valuation theory under liquidity constraints without permanent price impact, and illustrate the theory with examples. In Section 3, we present our method to value illiquid portfolios with linear permanent price impact functions. Finally, we conclude in Section 4 and show possible avenues for further research. 


\section{Portfolio Valuation without Permanent Price Impact}

In this section, we combine the notation of Acerbi and Scandolo (2008) and Csóka and Herings (2014) to summarize how, for a given period, the value of an illiquid portfolio can be defined without permanent price impact.

An investor can hold cash as well as risky assets from the set $N=$ $\{1, \ldots, n\}$. Let $\mathbf{p}=\left(p_{0}, \mathbf{p}^{n}\right)=\left(p_{0}, p_{1}, \ldots, p_{n}\right) \in \mathbb{R} \times \mathbb{R}^{n}$ denote a portfolio, where $p_{0}$ is the amount of cash in the portfolio $\left(p_{0}<0\right.$ means an immediate payment requirement) and $p_{i}$ is the number of assets held from asset $i \in N$. Let $\mathcal{P} \in \mathbb{R} \times \mathbb{R}^{n}$ denote the space of portfolios. Moreover, let $\mathbf{p} \oplus a$ denote adding $a \in \mathbb{R}$ amount of cash to portfolio $\mathbf{p} \in \mathcal{P}$, which results in portfolio $\mathbf{q} \in \mathcal{P}$ satisfying $q_{0}=p_{0}+a$ and $q_{i}=p_{i}$ for all $i \in N$.

The value of a portfolio depends on the order books for the risky assets to be specified as follows. We follow Çetin et al. (2004), Jarrow and Protter (2005) and Acerbi and Scandolo (2008) in modeling the order books for every asset $i \in N$ by a marginal supply-demand curve (MSDC) $m_{i}$.

Definition 2.1. The marginal supply-demand curve (MSDC) for asset $i \in N$ is given by the map $m_{i}: \mathbb{R} \backslash\{0\} \mapsto \mathbb{R}$ satisfying

(i) $m_{i}(x) \geq m_{i}(\bar{x})$ if $x<\bar{x}$;

(ii) $m_{i}(x)$ is right-continuous with left limits for $x<0$ and left-continuous with right limits for $x>0$.

The amount $m_{i}(x)$ for $x>0$ expresses the marginal bids at which asset $i \in N$ can be sold. Similarly, $m_{i}(x)$ for $x<0$ represents the marginal asks at which asset $i$ can be bought. Let $m_{i}\left(0^{+}\right)$denote the best bid and $m_{i}\left(0^{-}\right)$ the best ask price of asset $i \in N$. For negative (positive) values of $x$ the MSDC $m_{i}(x)$ corresponds to the supply (demand) of asset $i \in N$ by others. On top of the best bid and ask prices, MSDCs can, therefore, be used to represent both the supply and the demand side constraints in liquidity, even in a state-contingent way for modeling risk. Since we can work with any given period, the MSDCs are not necessary the order books, but they can also capture trading possibilities for different time horizons.

Note that the MSDCs are not defined at zero. Since we are working with assets, it is natural to assume that $m_{i}(x) \geq 0$ for all $i \in N$. However, the MSDC of a contract (for instance a swap agreement) could admit positive and negative values as well.

The MSDCs can be used to calculate the liquidation value of a portfolio. 
Definition 2.2. The liquidation mark-to-market value of a portfolio $\mathbf{p} \in \mathcal{P}$ is defined by

$$
L(\mathbf{p})=p_{0}+\sum_{i=1}^{n} \int_{0}^{p_{i}} m_{i}(x) d x
$$

The liquidation mark-to-market value of a portfolio $L(\mathbf{p})$ is its initial cash, plus the proceeds one gets by liquidating the long positions and the amount of money to be paid for closing the short positions.

When calculating $L(\mathbf{p})$, it is implicitly assumed that all the positions are closed using the current MSDC. The other extreme is to use only the best bid prices for long positions and only the best ask prices for short positions.

Definition 2.3. The uppermost mark-to-market value of a portfolio $\mathbf{p} \in \mathcal{P}$ is defined by

$$
U(\mathbf{p})=p_{0}+\sum_{i=1}^{n}\left[m_{i}\left(0^{+}\right) \max \left(p_{i}, 0\right)+m_{i}\left(0^{-}\right) \min \left(p_{i}, 0\right)\right] .
$$

Depending on the MSDCs, the cost of prompt liquidation, which is the difference between the liquidation value and the uppermost mark-to-market value of a portfolio, can be substantially high. The extent, to which trade is required is related to the portfolio constraints, captured by the liquidity policy.

Definition 2.4. A liquidity policy $\mathcal{L} \subseteq \mathcal{P}$ is a closed and convex subset of the portfolio-space satisfying

1. if $\mathbf{p} \in \mathcal{L}$ and $a \geq 0$, then $\mathbf{p} \oplus a \in \mathcal{L}$,

2. if $\mathbf{p} \in \mathcal{L}$, then $\left(p_{0}, \mathbf{0}^{n}\right) \in \mathcal{L}$.

The liquidity policy serves as the acceptable set of portfolios specifying the desired portfolio vectors. The liquidity policy is a convex set, where starting from any portfolio in the set both more cash (1.) and no risky assets (2.) are acceptable. Starting from an acceptable portfolio at the frontier of the liquidity policy, having more risky assets requires weakly more cash to be acceptable, but as a special case, requiring strictly more cash is possible as well.

As another special case, we will consider a cash liquidity policy with no short positions (Csóka, 2017), where the acceptable portfolio should have $c$ units of cash and short positions should be closed. 
Definition 2.5. Given $c \in \mathbb{R}$, the $c$-cash liquidity policy with no short positions $\mathcal{L}^{+}(c)$ is given by

$$
\mathcal{L}^{+}(c)=\left\{\left(p_{0}, \mathbf{p}^{n}\right) \in \mathcal{P} \mid p_{0} \geq c \text { and } \mathbf{p}^{n} \geq \mathbf{0}^{n}\right\} .
$$

Note that the required cash $c$ could be negative as well.

As we will see, the value of a portfolio in this framework depends on how we can reach the liquidity policy from it. A portfolio is attainable from another portfolio if we can reach both the level of cash and the number of risky assets in it by trading.

Definition 2.6. Given a portfolio $\mathbf{p} \in \mathcal{P}$, the portfolio $\mathbf{q} \in \mathcal{P}$ is attainable from $p, \mathbf{q} \in A t t(\mathbf{p}) \subseteq \mathcal{P}$ if there is $\mathbf{r} \in \mathcal{P}$ such that

$$
\mathbf{q}=\mathbf{p}-\mathbf{r} \oplus L(\mathbf{r})
$$

The liquidated part $\mathbf{r}$ has typically long positions, and then $L(\mathbf{r})$ provides more cash. However, $\mathbf{r}$ could also have short positions, meaning that there will be more from those assets in the new portfolio, which requires cash. Given a period, the (mark-to-market) value of a portfolio is defined as follows.

Definition 2.7 (Acerbi and Scandolo (2008)). The mark-to-market value of portfolio $\mathbf{p} \in \mathcal{P}$ under the liquidity policy $\mathcal{L}$ is a function $V^{\mathcal{L}}: \mathcal{P} \rightarrow \mathbb{R}$ defined by

$$
V^{\mathcal{L}}(\mathbf{p})=\sup \{U(\mathbf{q}) \mid \mathbf{q} \in \operatorname{Att}(\mathbf{p}) \cap \mathcal{L}\} .
$$

In (1), we are looking for the most valuable portfolio which is attainable from the initial one and satisfies the liquidity policy. Note that in $U(\mathbf{q})$ the original MSDC is used, assuming full recovery of the (generalized) order book.

According to the next proposition, this portfolio can be found as a solution of a convex optimization problem, which is crucial for industry implementation.

Proposition 2.8 (Acerbi and Scandolo (2008)). The optimization problem (1) in $\boldsymbol{q}$ is equivalent to a convex optimization problem in $\boldsymbol{r}$, given by

$$
V^{\mathcal{L}}(\boldsymbol{p})=\sup \left\{U(\boldsymbol{p}-\boldsymbol{r})+L(\boldsymbol{r}) \mid \boldsymbol{r} \in C_{\mathcal{L}}(\boldsymbol{p})\right\},
$$

where $C_{\mathcal{L}}(\boldsymbol{p})$ is a convex set given by

$$
C_{\mathcal{L}}(\boldsymbol{p})=\{\boldsymbol{r} \mid \boldsymbol{p}-\boldsymbol{r} \oplus L(\boldsymbol{r}) \in \mathcal{L}\}
$$

If $C_{\mathcal{L}}(\boldsymbol{p})$ is empty, then $V^{\mathcal{L}}(\boldsymbol{p})=-\infty$, else the supremum $V^{\mathcal{L}}(\boldsymbol{p}) \in \mathbb{R}$. 
To illustrate the definitions, we provide the following example.

Example 2.9. Consider a market with cash and one risky asset, where the space of portfolios is given by $\mathcal{P}=\mathbb{R}^{2}$. We are interested in the value of the initial portfolio $\mathbf{p}=\left(p_{0}, p_{1}\right)=(4,4)$, that is we have 4 units of cash and 4 units of an illiquid risky asset. Assume that the MSDC of the risky asset is given by

$$
m_{1}(x)= \begin{cases}5 & \text { if } x<0 \\ 4 & \text { if } 0<x \leq 1, \\ 2 & \text { if } 1<x \leq 3, \\ 1 & \text { if } 3<x .\end{cases}
$$

We can calculate the liquidation and the uppermost mark-to-market value of $\mathbf{p}$ as

$$
\begin{array}{r}
L(\mathbf{p})=4+4 \times 1+2 \times 2+1 \times 1=13 \\
U(\mathbf{p})=4+4 \times 4=20 .
\end{array}
$$

Suppose that the liquidity policy is the 10-cash liquidity policy with no short positions $\mathcal{L}^{+}(10)$, where the acceptable portfolio should have 10 units of cash and short positions should be closed.

In $\mathbf{p}$, there are 4 units of cash and no short positions, so we need 6 more units of cash. To meet the liquidity policy, we can do nothing else but sell 2 units of the risky asset, $\mathbf{r}=(0,2)$. The first unit is sold for 4 , and the second unit for $2, \mathrm{~L}(\mathbf{r})=6$. Indeed, we get that $\mathbf{q}=\mathbf{p}-\mathbf{r}+L(\mathbf{r})=(10,2) \in$ $\operatorname{Att}(\mathbf{p}) \cap \mathcal{L}^{+}(10)$. The mark-to-market value of $\mathbf{p}$ is

$$
V^{\mathcal{L}^{+}(10)}(\mathbf{p})=U(\mathbf{q})=10+4 \times 2=18 .
$$

In the spirit of Proposition 2.8, we get the same number from $U(\mathbf{p}-\mathbf{r})+$ $L(\mathbf{r})=4+4 \times 2+6=18$.

Notice that even though we have sold 2 units, the resulting portfolio was valued using the original MSDC. The implicit assumption is that liquidity recovers by new limit orders, trade has no permanent price impact.

With full permanent price impact and hence no new limit orders, only one more unit could be sold for 2 and the rest for 1 , that is the modified MSDC of the risky asset would be

$$
\hat{m}_{1}(x)= \begin{cases}5 & \text { if } x<0 \\ 2 & \text { if } 0<x \leq 1 \\ 1 & \text { if } 1<x\end{cases}
$$

Using $\hat{m}_{1}$, the uppermost mark-to-market value of $\mathbf{q}$ is $\hat{U}(\mathbf{q})=10+2 \times 2=14$, which is, of course, lower. 
Motivated by Example 2.9, in the next section we incorporate the effects of permanent price impact on the valuation of illiquid portfolios.

\section{Portfolio Valuation with Linear Permanent Price Impact}

In this paper, we use a linear permanent price impact function. Huberman and Stanzl (2004) shows that a linear permanent price impact function is needed for arbitrage-free pricing. Furthermore, Almgren et al. (2005) tests empirically and cannot reject the hypothesis of a linear permanent price impact. Translated to MSDCs, a linear permanent price impact means that depending on the size of the trade, we expect that selling decreases and buying increases the level of the MSDC linearly, formally defined as follows.

Definition 3.1. Let a risky asset $i \in N$, its MSDC $m_{i}$, and a parameter $\beta_{i} \in \mathbb{R}^{+}$be given. After liquidating $r_{i} \in \mathbb{R}$ amount of asset $i$, the $M S D C$ of asset $i$, modified with linear permanent price impact $\bar{m}_{i}^{\beta_{i}}(x)$ is given by

$$
\bar{m}_{i}^{\beta_{i}}(x)=m_{i}(x)-\beta_{i} r_{i} .
$$

Again, $r_{i}>0$ means selling, $r_{i}<0$ means buying from asset $i$.

Let us reconsider Example 2.9 with a linear permanent price impact.

Example 3.2. [Example 2.9 continued.] Suppose a linear permanent impact function with $\beta_{1}=0.2$. Since we still can do nothing else but liquidate 2 units of asset 1 , the initial MSDC is lowered by $2 \times 0.2$ and the MSDC of asset 1 , modified with linear permanent price impact $\bar{m}_{1}^{0.2}(x)$ becomes

$$
\bar{m}_{1}^{0.2}(x)= \begin{cases}4.6 & \text { if } x<0 \\ 3.6 & \text { if } 0<x \leq 1 \\ 1.6 & \text { if } 1<x \leq 3 \\ 0.6 & \text { if } 3<x\end{cases}
$$

Using $\bar{m}_{1}^{0.2}$, the uppermost mark-to-market value of $\mathbf{q}$ is

$$
\bar{U}(\mathbf{q})=10+3.6 \times 2=17.2,
$$

which is somewhere in between the case with no permanent price impact and full permanent price impact.

Given the linear price impact parameters $\beta_{i} \in \mathbb{R}^{+}$for each $i \in N$, analogously to Definition 2.3 , let $\bar{U}$ denote the uppermost mark-to-market value 
function with linear price impact, calculated from the MSDCs modified with linear permanent price impact, that is from $\bar{m}_{i}^{\beta_{i}}$ for each $i \in N$.

Now, given a period, we can define the mark-to-market value of a portfolio with linear permanent price impact.

Definition 3.3. Given $\beta_{i} \in \mathbb{R}^{+}$for each $i \in N$, the mark-to-market value of portfolio $\boldsymbol{p} \in \mathcal{P}$ with linear permanent price impact under the liquidity policy $\mathcal{L}$ is a function $\bar{V}^{\mathcal{L}}: \mathcal{P} \rightarrow \mathbb{R}$ defined by

$$
\bar{V}^{\mathcal{L}}(\mathbf{p})=\sup \{\bar{U}(\mathbf{q}) \mid \mathbf{q} \in \operatorname{Att}(\mathbf{p}) \cap \mathcal{L}\} .
$$

Note that the set of attainable portfolios $\operatorname{Att}(\mathbf{p})$ is calculated using the original MSDCs, whereas in $\bar{U}(\mathbf{q})$ the MSDCs are modified with linear permanent price impacts.

Analogously to Proposition 2.8, using Definition 2.6 and $\mathbf{q}=\mathbf{p}-\mathbf{r} \oplus L(\mathbf{r})$ we get the following proposition.

Proposition 3.4. Given $\beta_{i} \in \mathbb{R}^{+}$for each $i \in N$, the optimization problem (3) in $\boldsymbol{q}$ is equivalent to an optimization problem in $\boldsymbol{r}$, given by

$$
\bar{V}^{\mathcal{L}}(\boldsymbol{p})=\sup \left\{\bar{U}(\boldsymbol{p}-\boldsymbol{r})+L(\boldsymbol{r}) \mid \boldsymbol{r} \in C_{\mathcal{L}}(\boldsymbol{p})\right\}
$$

where $C_{\mathcal{L}}(\boldsymbol{p})$ is again a convex set given by

$$
C_{\mathcal{L}}(\boldsymbol{p})=\{\boldsymbol{r} \mid \boldsymbol{p}-\boldsymbol{r} \oplus L(\boldsymbol{r}) \in \mathcal{L}\}
$$

If $C_{\mathcal{L}}(\boldsymbol{p})$ is empty, then $V^{\mathcal{L}}(\boldsymbol{p})=-\infty$, else the supremum $V^{\mathcal{L}}(\boldsymbol{p}) \in \mathbb{R}$.

Note that in Proposition 3.4, we just claim a general optimization problem and not a convex one, due to the appearance of $\bar{U}$.

Example 3.5 (Examples 2.9 and 3.2 continued.). Let us extend the market to two risky assets, so the space of portfolios is now given by $\mathcal{P}=\mathbb{R}^{3}$.

Suppose that in the initial portfolio there are also 4 units of a second risky asset, that is $\mathbf{p}=\left(p_{0}, p_{1}, p_{2}\right)=(4,4,4)$.

Let the MSDC of asset 2 be given by

$$
m_{2}(x)= \begin{cases}2 & \text { if } x<0 \\ 1 & \text { if } 0<x \leq 1 \\ 0.6 & \text { if } 1<x .\end{cases}
$$

Let asset 2 also have a linear permanent price impact parameter of 0.2 , that is let $\beta_{1}=\beta_{2}=0.2$. Finally, let us keep the 10 -cash liquidity policy 
with no short positions $\mathcal{L}^{+}(10)$. If there is no permanent price impact and liquidity recovers, then using Proposition 2.8 we get that it is optimal to liquidate $\mathbf{r}^{*}=\left(0,1, \frac{8}{3}\right)$ to get the additional liquidity of $L\left(\mathbf{r}^{*}\right)=6$ and we obtain $\mathbf{q}^{*}=\mathbf{p}-\mathbf{r}^{*}=\left(10,3, \frac{4}{3}\right)$. The mark-to-market value of $\mathbf{p}$ is then

$$
V^{\mathcal{L}^{+}(10)}(\mathbf{p})=U\left(\mathbf{q}^{*}\right)=10+4 \times 3+1 \times \frac{4}{3}=\frac{70}{3} \approx 23.33 .
$$

If there is permanent price impact, then, after solving (4), the new optimum is to liquidate $\mathbf{r}^{* *}=(0,0.8,4)$ to get the additional liquidity of $L\left(\mathbf{r}^{* *}\right)=$ 6 and we obtain $\mathbf{q}^{* *}=(10,3.2,0)$. The new best bid of asset 1 becomes $4-0.8 \times 0.2=3.84$ and we get that the mark-to-market value of $\mathbf{p}$ with linear permanent price impact is

$$
\bar{V}^{\mathcal{L}^{+}(10)}(\mathbf{p})=\bar{U}\left(\mathbf{q}^{* *}\right)=10+3.84 \times 3.2=22.288 .
$$

Note that using the optimal trade with no permanent price impact $\mathbf{r}^{*}=$ $\left(0,1, \frac{8}{3}\right)$ would result in this case $\mathbf{q}^{*}=\left(10,3, \frac{4}{3}\right)$, and the new best bids of asset 1 and asset 2 would be $4-1 \times 0.2=3.8$ and $1-\frac{8}{3} \times 0.2=\frac{7}{15}$ respectively. Then $\bar{U}\left(\mathbf{q}^{*}\right)=10+3.8 \times 3+\frac{7}{15} \times \frac{4}{3}=\frac{991}{45} \approx 22.02<22.228=\bar{U}\left(\mathbf{q}^{* *}\right)$, which is, of course, not optimal.

Intuitively, there is an endowment effect on top of the transaction cost effect that should be taken into account with permanent price impacts. The trade-off is between trading more from a relatively liquid asset to have lower transaction costs and trading less to cause lower permanent price impact on the remaining endowment from the particular asset.

To give more insights about the problem in (4), in the rest of the paper we assume continuous MSDCs such that they are defined at zero, implying that $m_{i}(0)=m_{i}\left(0^{+}\right)=m_{i}\left(0^{-}\right)$for all $i \in N$. Moreover, we work with a $c$-cash liquidity policy with no short positions $\mathcal{L}^{+}(c)$. Then we have the following formulation of the optimization problem.

Proposition 3.6. Given $\beta_{i} \in \mathbb{R}^{+}$and continuous MSDCs $m_{i}$ for each $i \in N$, and $\mathcal{L}^{+}(c)$, the optimization problem (4) is equivalent to an optimization problem in $\boldsymbol{r}$, given by

$$
\bar{V}^{\mathcal{L}^{+}(c)}(\boldsymbol{p})=\max (\bar{U}(\boldsymbol{p}-\boldsymbol{r})+L(\boldsymbol{r}))
$$

subject to

$$
\begin{aligned}
p_{0}-r_{0}+L(\boldsymbol{r}) & =c, \text { and } \\
p_{i}-r_{i} & \geq 0 \text { for all } i \in N .
\end{aligned}
$$


Proof. Due to the $c$-cash liquidity policy with no short positions $\mathcal{L}^{+}(c)$, the supremum can be changed to maximum and we get the first constraint in (5). The second constraint makes sure that new short positions are not opened for $p_{i}>0$ and old short positions are closed for $p_{i}<0$.

To solve (5), recall that using continuous MSDSs the uppermost markto-market value function with linear price impact $\bar{U}$ is given by

$$
\bar{U}(\mathbf{p}-\mathbf{r})=p_{0}-r_{0}+\sum_{i=1}^{n}\left[m_{i}(0)-\beta_{i} r_{i}\right]\left(p_{i}-r_{i}\right) .
$$

Based on Boyd and Vandenberghe (2004), we can use the Karush-KuhnTucker conditions to find the solution of (5). The Lagrange function is given by

$$
G(\mathbf{r}, \lambda, \mu)=-\bar{U}(\mathbf{p}-\mathbf{r})-L(\mathbf{r})-\lambda\left[p_{0}-r_{0}+L(\mathbf{r})-c\right]-\sum_{i=1}^{n} \mu_{i}\left[p_{i}-r_{i}\right],
$$

or, using (6) and Definition 2.2 it is

$$
\begin{array}{r}
G(\mathbf{r}, \lambda, \mu)=-p_{0}-\sum_{i=1}^{n}\left[m_{i}(0)-\beta_{i} r_{i}\right]\left(p_{i}-r_{i}\right)-\sum_{i=1}^{n} \int_{0}^{r_{i}} m_{i}(x) d x \\
-\lambda\left[\sum_{i=1}^{n} \int_{0}^{r_{i}} m_{i}(x) d x+p_{0}-c\right]-\sum_{i=1}^{n} \mu_{i}\left[p_{i}-r_{i}\right] .
\end{array}
$$

Let $r_{i}^{* *}$ denote the optimal $r_{i}$ for all $i \in N$. Without loss of generality, we can assume that $r_{0}^{* *}=0$, since the optimization problem does not depend on the level of cash.

The Karush-Kuhn-Tucker conditions are as follows. First,

$\frac{\partial G(\mathbf{r}, \lambda, \mu)}{\partial r_{i}}=m_{i}(0)-2 \beta_{i} r_{i}^{* *}+\beta_{i} p_{i}-(1+\lambda) m_{i}\left(r_{i}^{* *}\right)+\mu_{i}=0$ for all $i \in N$.

Primal feasibility requires that

$$
\begin{aligned}
& \frac{\partial G(\mathbf{r}, \lambda, \mu)}{\partial \lambda}=\sum_{i=1}^{n} \int_{0}^{r_{i}^{* *}} m_{i}(x) d x+p_{0}-c=0, \text { and } \\
& \frac{\partial G(\mathbf{r}, \lambda, \mu)}{\partial \mu_{i}}=p_{i}-r_{i}^{* *} \geq 0 .
\end{aligned}
$$

Due to complementary slackness we have that

$$
\mu_{i}\left[p_{i}-r_{i}^{* *}\right]=0 \text { for all } i \in N .
$$


Finally, dual feasibility requires that

$$
\mu_{i} \geq 0 \text { for all } i \in N \text {. }
$$

Now we can formally see the intuition of Example 3.5. Suppose that $p_{i}-r_{i}^{* *}>0$. Then $-2 \beta_{i} r_{i}^{* *}+\beta_{i} p_{i}$ appears in the partial derivative of the Lagrangian function with respect to $r_{i}$. So $\mathbf{r}$ depends on the initial portfolio $\mathbf{p}$ and the permanent price impact parameters, and the marginal revenue (cost) at $r_{i}^{* *}>0\left(r_{i}^{* *}<0\right)$ controlling both for the endowment effect and the transaction cost effect.

Solving the problem requires numerical methods or further assumptions. To get analytical results, one can approximate the MSDCs with exponential functions (Tian et al. 2013).

\section{Conclusion}

To take into account both the temporary and the permanent price impacts of trading by institutional investors, for a given period, we provided an optimization problem for portfolio valuation under liquidity constraints with linear permanent price impact. We showed that incorporating permanent price impact could have substantial effects on the optimal trading strategy. Given the cash and the number of assets in the portfolio, the building blocks of our model are the MSDCs and the linear price impact parameters of the assets, and the liquidity policy specifying the portfolio constraints. All blocks could be state contingent for modeling liquidity risk and market risk together, running stress tests, and calculating capital requirements.

There are many possible extensions for further research. One could model nonlinear price impacts or a price impact which is not shifting all the points of the MSDC in a parallel way. In fact, one of the reasons that we assume that short positions should be closed is that by huge short-selling from an asset, the parallel shift of its MSDC results in negative prices at which short positions could be closed and then the optimization problem has no solution. For industry implementation, the underlying optimization problem could be further investigated, even for more general liquidity policies. Our method could also be adjusted for hedging under liquidity constraints (Dömötör. 2017). Finally, we worked for a given period, but adding time as an extra dimension would also be interesting. 


\section{References}

Acerbi, C., Scandolo, G., 2008. Liquidity risk theory and coherent measures of risk. Quantitative Finance 8 (7), 681-692.

Almgren, R., 2003. Optimal execution with nonlinear impact functions and trading-enhanced risk. Applied Mathematical Finance 10, 1-18.

Almgren, R., Chriss, N., 2000. Optimal execution of portfolio transactions. Journal of Risk 3, 5-39.

Almgren, R., Thum, C., Hauptmann, E., Li, H., 2005. Equity market impact. Quantitative Trading 10, 21-28.

Alzahrani, A. A., Gregoriou, A., Hudson, R., 2012. Can market frictions really explain the price impact asymmetry of block trades? evidence from the saudi stock market. Emerging Markets Review 13, 202-209.

Boyd, S., Vandenberghe, L., 2004. Convex Optimization. Cambridge University Press.

Çetin, U., Jarrow, R. A., Protter, P., 2004. Liquidity risk and arbitrage pricing theory. Finance and Stochastics 8, 311-341.

Csóka, P., 2017. Fair risk allocation in illiquid markets. Finance Research Letters 21, 228-234.

Csóka, P., Herings, P. J.-J., 2014. Risk allocation under liquidity constraints. Journal of Banking and Finance 49 (C), 1-9.

Dömötör, B., 2017. Optimal hedge ratio in a biased forward market under liquidity constraints. Finance Research Letters 21, 259-263.

Han, J., Ryu, D., Ryu, D., Webb, R. I., 2016. The price impact of futures trades and their intraday seasonality. Emerging Markets Review 26, 80-98.

Huberman, G., Stanzl, W., 2004. Price manipulation and quasi-arbitrage. Econometrica 72 (4), 1247-1275.

Jarrow, R. A., Protter, P., 2005. Liquidity risk and risk measure computation. Review of Futures Markets 11, 27-39.

Kitamura, Y., 2016. The probability of informed trading measured with priceimpact, price reversal, and volatility. Journal of International Financial Markets, Institutions \& Money 42, 77-90. 
Tian, Y., Rood, R., Oosterlee, C. W., February 2013. Efficient portfolio valuation incorporating liquidity risk. Quantitative Finance, 1-21. 